\title{
Peranan microRNA dalam diagnosis dan tata laksana kanker payudara
}

\author{
Wirsma Arif Harahap \\ Bagian Bedah Onkologi, Fakultas Kedokteran, Universitas Andalas/RSUP dr. M. Djamil Padang \\ Korespondensi: Wirsma Arif Harahap; email: wirsma@med.unand.ac.id
}

\begin{abstract}
Abstrak
Epigenetik adalah suatu perubahan ekspresi gen yang dapat diturunkan namun tidak terdapat perubahan sekuen DNA pada gen tersebut. Saat ini diperlukan adanya identifikasi proses epigenetik peranan microRNA dalam diagnosis dan tatalaksana kanker payudara. Tujuan: Penelitian ini bertujuan untuk mengidentifikasi peran microRNA (miRNA) dalam diagnosis dan tatalaksana kanker payudara. Metode: Penelitian ini merupakan literature review terhadap artikel penelitian yang terpublikasi secara internasional pada database Pubmed/Medline dan Proquest dari tahun 1998-2019. Studi literatur ini disusun berdasarkan panduan Walker dan Avant. Hasil: Peranan miRNA yang dapat menginduksi dan dapat juga mencegah kanker serta peranannya dalam tingkat agresivitas kanker menjadikan mikro molekul dapat dijadikan biomarker untuk deteksi dini dan penilaian agresivitas kanker payudara (KPD). Lepasnya miRNA dari tumor ke dalam sirkulasi darah dapat dijadikan indikator biomarker baik sebagai diagnostik, prognostik, dan prediktif. level ekspresi miRNA juga dapat dijadikan monitor terhadap status tumor, sehingga menjadi catatan penting bahwa pengangkatan primer tumor akan mengurasi jumlah miRNA yang bersirkulasi di dalam darah. Simpulan: miRNA dapat digunakan baik sebagai biomarker pada KPD dan juga sebagai bagian dari terapi KPD.

Kata kunci: microRNA; diagnosis; tata laksana; kanker payudara
\end{abstract}

\begin{abstract}
Epigenetics is a change in gene expression that can be derived but there is no change in the DNA sequence in that gene. At present it is necessary to identify the epigenetic role process of microRNA in the diagnosis and management of breast cancer. Objective: This study aims to identify the role of microRNA in the diagnosis and management of breast cancer. Method: This research conducted a literature review of research articles published in the Pubmed/Medline and Proquest databases from 1998-2019. This literature study was prepared based on Walker and Avant's guide. Results: The role of miRNA that can induce and can also prevent cancer and its role in the level of cancer aggressiveness makes micro molecules can be used as biomarkers for early detection and assessment of breast cancer aggressiveness. The release of miRNA from the tumor into the blood circulation can be used as an indicator of biomarkers both as a diagnostic, prognostic and predictive. miRNA expression levels can also be monitored for tumor status, so it is important to note that primary removal of the tumor will reduce the amount of miRNA circulating in the blood. Conclusion: miRNA can be used both as a biomarker of breast cancer and also as part of breast cancer therapy.
\end{abstract}

Keywords: microRNA; diagnosis; management; breast cancer 


\section{PENDAHULUAN}

Perubahan sel normal secara onkogenesis dalam menjadi kanker payudara (KPD) dapat disebabkan oleh tiga faktor yaitu: perubahan genetik, perubahan hormonal, dan perubahan lingkungan. Onkogenesis KPD terjadi dengan mulai terganggunya kestabilan gen baik akibat faktor eksogen maupun faktor endogen yang selanjutnya mempengaruhi keseimbangan 3 jenis gen yaitu onkogen, gen DNA repair dan gen tumor supresor. Pada saat ini telah diketahui hampir 64 persen kasus sudah diketahui mutasi gen yang bertanggung jawab dalam timbulnya KPD seperti gen BRCA1 dan 2, ATM, PTEN, CHEK2 dan seterusnya. ${ }^{1}$ Namun masih terdapat $36 \%$ sisanya masih belum diketahui adanya mutasi gen namun kemungkinan diduga faktor epigenetik memainkan peranan dalam hal ini. ${ }^{2}$ Proses epigenetik adalah suatu sebagai perubahan ekspresi gen yang diturunkan, namun tidak disandi oleh perubahan sekuens DNA yang terkait. ${ }^{3}$ Proses epigenetik mencakup metilasi DNA dan histon modifikasi dan microRNA (miRNA). Epigenetik adalah suatu perubahan ekspresi gen yang dapat diturunkan namun tidak terdapat perubahan sekuens DNA pada gen tersebut. Sampai saat ini sudah diketahui 3 proses epigenetik yaitu metilasi DNA, modifikasi histon dan miRNA. ${ }^{4}$

miRNA adalah bagian dari tipe RNA yang tidak memberikan kode untuk pembentukan protein namun mempunyai peranan penting dalam regulasi ekspresi gen. Pada kanker, miRNA mempunyai peranan untuk mempengaruhi onkogen maupun juga sebagai gen tumor supresor karena sudah dibuktikan bahwa 1 miRNA dapat berperan untuk mempengaruhi ekspresi lebih dari 2 gen. miRNA ditemukan pada tahun 1993 oleh Rosalind Lee dan Rhonda Feinbaum pada penelitian gen lin-14 pada cacing $C$. Elegans. miRNA adalah non-coding molekul kecil RNA (terdiri dari 19-23 nukleotida) yang mengontrol ekspresi gen. Dapat ditemukan pada tanaman, hewan, dan beberapa virus. miRNA berpasangan bersama basa yang akan melengkapi sekuens di dalam molekul messenger RNA (mRNA), sebagai hasilnya molekul mRNA akan berada pada posisi diam melalui satu atau lebih. Pembelahan jalinan $m R N A$ menjadi dua, destabilisasi mRNA melalui pemendekan, menurunkan efisiensi translasi $m R N A$ oleh ribosom. . $^{5,6}$

\section{METODE}

Jenis penelitian yang dilakukan dengan menggunakan desain literature review terhadap artikel penelitian yang terpublikasi secara internasional pada database Pubmed/Medline dan Proquest dari tahun 1998-2019. Pengumpulan data dilakukan dengan menggunakan pencarian secara online dengan menggunakan kata kunci: "breast cancer AND management AND diagnosis AND role AND microRNA OR miRNA". Studi literatur ini disusun berdasarkan panduan Walker dan Avant yang terdiri dari pengkajian yaitu: a) pemahaman konsep; (b) identifikasi peran atau tujuan; (c) mengidentifikasi semua 
konsep dan kaitannya dengan peran atau tujuan. $^{7}$

\section{HASIL DAN PEMBAHASAN}

\section{Peranan dan Fungsi miRNA}

Pada saat ini telah ditemukan 18.226 miRNA dari 50 organisme yang terdaftar pada database RNA (http://www.mirbase.org/). Pada manusia sudah dikenal lebih dari 1000 miRNA. Peranan utama dari miRNA adalah sebagai regulator pada tahap pasca-transkripsi dari ekspresi gen yang mengatur hampir $60 \%$ dari semua kode protein pada mamalia. Karena fungsinya sebagai regulator maka miRNA berperan dalam regulasi hampir di semua proses seluler seperti perkembangan, diferensiasi, proliferasi dan apoptosis. ${ }^{8}$ Fungsi miRNA dalam regulator ekspresi gen dijalankan melalui proses degradasi $m R N A$ yang selanjutnya akan menghambat translasi dan modulasi proses selular.

Hampir 30 persen dari gen miRNA terletak di intron gen penyandi protein yang ditemukan pada untai sense yang menunjukkan adanya tautan miRNA dan mRNA. ${ }^{9}$ miRNA manusia berada dalam semua kromosom kecuali pada kromosom $Y$ dan terletak pada area tertentu atau tidak acak. Walaupun miRNA terletak pada intron ataupun exon dari gen proteincoding, namun sebagian besar dari miRNA tersebut ditemukan pada daerah intron di non coding. ${ }^{8,9}$ Dilihat dari posisi miRNA dalam kromosom, ternyata lebih dari setengah gen miRNA terdapat pada bagian kromosom yang sangat rentan terhadap duplikasi, delesi, dan mutasi sel pada proses perkembangan kanker. Area ini dapat memberikan pengaruh terhadap ekspresi miRNA.

Tabel 1. Kelebihan dan Kekurangan Metode Pemeriksaan miRNA ${ }^{12}$

\begin{tabular}{lll}
\hline Method & Advantages & Disadvantages \\
\hline $\begin{array}{l}\text { Quantitative real-time } \\
\text { PCR }\end{array}$ & Highly sensitive & $\begin{array}{l}\text { Mostly used to quantify the level of a defined set of } \\
\text { miRNAs }\end{array}$ \\
Microarray & $\begin{array}{l}\text { Requires small amounts of input RNA } \\
\text { Can simultaneously measure large numbers of } \\
\text { circulating miRNAs }\end{array}$ & $\begin{array}{l}\text { Low dynamic range } \\
\text { Unable to detect novel unannotated miRNAs }\end{array}$ \\
$\begin{array}{l}\text { Next-generation } \\
\text { sequencing }\end{array}$ & $\begin{array}{l}\text { Can detect both annotated and unannotated } \\
\text { miRNAs }\end{array}$ & $\begin{array}{l}\text { Generates copious amounts of data requiring compli } \\
\text { bioinformatics data analysis }\end{array}$ \\
NanoString nCounter & Can quantify the exact copy number of miRNA & Currently limited to detecting up to 800 miRNAs per \\
& sample
\end{tabular}

Penelitian bioinformatika melalui in-sillico dan microarray mengungkapkan bahwa satu miRNA dapat bekerja pada lebih dari dua gen target yang berfungsi baik sebagai faktor transkripsi, reseptor, faktor yang disekresikan maupun transporter. ${ }^{10}$ MicroRNAs berpartisipasi pada tahap awal pasca-transkripsi ekspresi gen.
Berdasarkan mekanisme kerjanya pada gen target, maka microRNA mempunyai dua fungsi yaitu sebagai miRNA onkogenik (oncomiR) yang bekerja menghambat gen tumor supresor dan sebagai miRNA tumor suppressor (Tumor suppressor miR) yang berperan menghambat ekspresi gen oncogene. ${ }^{11}$ 


\section{Metode Pemeriksaan miRNA}

miRNA yang bersirkulasi di dalam darah dapat diukur secara kuantitatif. Beberapa metode dapat digunakan untuk mengukur miRNA yang bersirkulasi di dalam darah. Pengukuran tersebut dapat dilakukan dengan quantitative real-time $P C R$, microarray, Next Generation Sequencing, dan nanoString counter. ${ }^{12}$ Masing-masing metode memiliki kelebihan dan kekurangannya masing-masing seperti yang diterangkan dalam tabel 1.

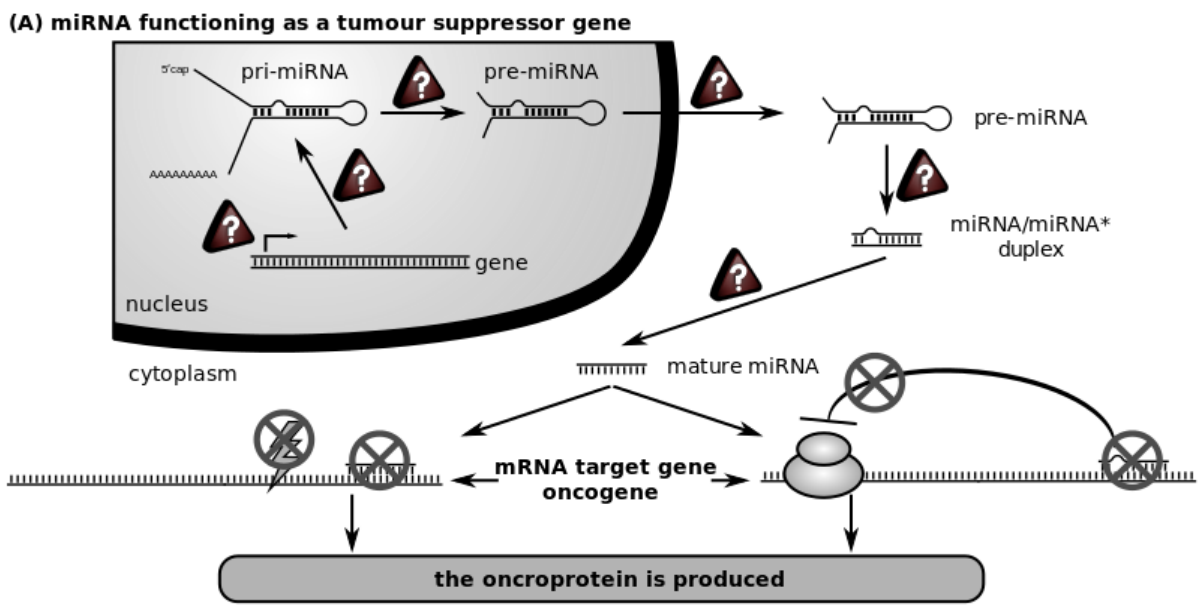

Gambar 1. Fungsi miRNA terhadap tumor supressor gene

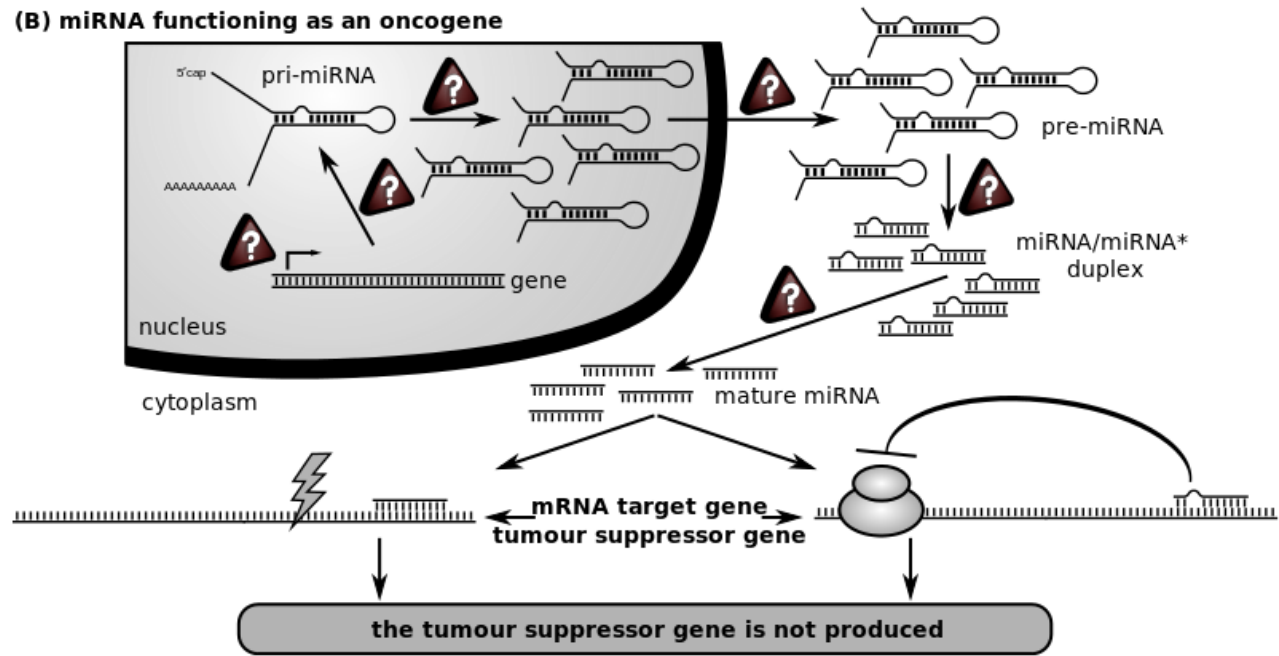

Gambar 2. Fungsi miRNA sebagai oncogene

Metode yang paling banyak digunakan adalah Quantitatif reverse transcriptase real-time $P C R$ karena metode ini yang paling sensitif dan hanya membutuhkan sedikit sampel RNA. Jumlah dari miRNA yang bersirkulasi di dalam darah sangat bergantung kepada tipe sampel dan metode ekstraksi RNA. Serum dan plasma adalah sampel yang paling sering digunakan untuk mendeteksi miRNA yang bersirkulasi. 
Tabel 2. Klasifikasi miRNA onkogenik terkait dengan kanker payudara ${ }^{14}$

\begin{tabular}{lll}
\hline \multicolumn{1}{c}{ miRNA (family) } & \multicolumn{1}{c}{ Identified target } & \multicolumn{1}{c}{ Associate event } \\
\hline miR-21 & TIMP1, PDCD4, TIMP3, PTEN & Cancer metastasis \\
miR-155 & FOXO3a, SOCS1, Caspase-3, & Cell proliferation and apoptosis \\
& TP53INP1 & \\
miR-182 & RECK, MIM, FOXO1 & Cell invasion, colony formation \\
miR-10b & HOXD10, Tiam1 & Cell invasion, migration \\
miR-27a & HOXO1, ZBTB10 & Cell viability, angiogenesis \\
miR-9 & E-Cadherin & Cell motility and invasiveness, \\
& & angiogenesis \\
miR-22 & TET family & EMT \\
miR-181a & Bim & EMT, cancer metastasis \\
miR-373,miR-52c & CD44 & Cell migration and invasion \\
miR-375 & RASD1 & Cell proliferation \\
miR-221/222 & TRPS1, ADIPORI1, p27Kip1 & Cancer metastasis, tumor growth, \\
& & EMT \\
miR-632 & DNAJB6 & Cancer metastasis \\
miR-7, miR-218 & HOXB3 & Cell cycle, colony formation \\
miR-37a & WIF1, PTEN, WNT5A & Cancer metastasis \\
\hline
\end{tabular}

Peranan Micro-RNA pada Karsinogenesis KPD

Penelitian biomolekuler menunjukkan bahwa sebuah miRNA dapat mengurangi kestabilan ratusan $m R N A$. Penelitian yang lain juga menunjukkan bahwa satu molekul miRNA dapat menekan produktivitas ratusan protein. Penyakit pertama yang diketahui berhubungan dengan deregulasi miRNA adalah kronik limfositik leukemia. miRNA adalah salah satu faktor molekuler yang berperan pada kanker payudara. miRNA dapat berperan sebagai kanker supresor ataupun stimulator. Dengan menghambat onkogenik RNA maka miRNA diduga dapat berperan penting terhadap terapi kanker payudara. Reduksi pada ekspresi miRNA yang spesifik terhadap kanker payudara menunjukkan hasil dimana terjadi hambatan pembelahan sel dan apoptosis pada sel tersebut. ${ }^{12,13}$
Dari pembahasan di atas dapat dipahami bahwa miRNA memiliki peranan penting dalam proses terjadinya KPD. lorio et al merupakan orang yang pertama kali menggunakan miRNA microarray untuk melihat deregulasi miRNA pada kanker payudara. Dalam penelitiannya menemukan down-regulation miR-10b, miR-125b, dan miR-145, sementara itu upregulasi pada miR-21 and miR-155 dan menyimpulkan miRNA tersebut masingmasing bekerja sebagai tumor suppressor genes atau oncogenes. ${ }^{13} \mathrm{Hal}$ ini dapat dilihat pada gambar 1 dan 2 .

Gambar 1 menjelaskan bahwa miRNA memiliki fungsi sebagai tumor supressor gene yaitu miRNA yang sering mengalami amplifikasi atau ekspresi berlebihan di sel tumor dan target gennya. Fungsi miRNA lainnya dapat dilihat pada gambar 2 . Gambar 2 diketahui bahwa fungsi miRNA lainnya adalah sebagai oncogene yaitu 
miRNA yang dapat memicu perkembangan

kanker payudara.

Tabel 3. Klasifikasi miRNA yang berkaitan dengan peranannya sebagai tumor supresor pada kanker payudara $^{14}$

\begin{tabular}{|c|c|c|}
\hline miRNA (family) & Identified target & Associated event \\
\hline Let-7 family & $\begin{array}{l}\text { H-ras, HMGA2, PAK1, DIAPH2, } \\
\text { RDX, ITGBS }\end{array}$ & $\begin{array}{l}\text { Tumor initiation, cell differentiation } \\
\text { and metastasis, cell stemness, } \\
\text { maintenance }\end{array}$ \\
\hline $\operatorname{miR}-145$ & $\begin{array}{l}\text { IRS-1, ER- } \alpha, \text { RTKN, MUC1, OCT4, } \\
\text { N-Ras, VEGF-A }\end{array}$ & $\begin{array}{l}\text { Tumor growth, cell differentuiation, } \\
\text { invasion and metastasis, } \\
\text { angiogenesis }\end{array}$ \\
\hline MiR-200 family & ZEB1, ZEB2, HER3, Sec23a, SIRT1 & EMT, tumor growth and metastasis \\
\hline MiR205 & ZEB1, ZEB2, HER3 VEGF-A & $\begin{array}{l}\text { EMT, cell proliferation and invation, } \\
\text { CSC stemness promotion }\end{array}$ \\
\hline MiR-334 & $\begin{array}{l}\text { SOX4, fenascim C, ER- } \alpha, I G F 1, \\
R S P 1, \text { ID4 }\end{array}$ & $\begin{array}{l}\text { Tumor migration and invation, cell } \\
\text { viav|bility and apoptosis }\end{array}$ \\
\hline MiR-126 & IGFBP2, MERTK, PITPNCI & Metstasis, angiogenesis \\
\hline miR-30 family & $\begin{array}{l}\text { Ubc9, TWF1, Vimentin, Kras, } \\
\text { MTDH }\end{array}$ & $\begin{array}{l}\text { CSC self-renewal, cell apoptosis, } \\
\text { EMT }\end{array}$ \\
\hline $\operatorname{miR} 146 a / b$ & IL-1, RSK, NFRSF-6 & Cancer metastasis \\
\hline miR-17-20 cluster & Cyclin D1 & Cell Proliferation \\
\hline $\operatorname{miR}-26 b$ & SLC7.A11 & Cell apoptosis \\
\hline $\operatorname{miR}-290$ & $A r i-4 b$ & Tumor growth, cell apoptosis \\
\hline $\operatorname{miR}-27 b$ & Сур1B1 & Tumor Growth \\
\hline $\operatorname{miR}-31$ & $\begin{array}{l}\text { Integrin- } \alpha 5 \text {, radixin, RhoA, } \\
\text { WAVE3, PRKCE }\end{array}$ & Cancer metastasis, cell apoptosis \\
\hline $\operatorname{miR}-125 a / b$ & HER2, HER3 & Cell invasion \\
\hline $\operatorname{miR}-203$ & SNAI2 EMT, cell invasion & SNAI2 EMT, cell invasion \\
\hline $\operatorname{miR}-224$ & CDC42, CXCR4 Cancer metastasis & CDC42, CXCR4 Cancer metastasis \\
\hline $\operatorname{miR}-20 b$ & HIF-1, STAT3 & Angiogenesis \\
\hline $\operatorname{miR}-206$ & Cyclin D2 & Cell proliferation \\
\hline $\operatorname{miR}-342$ & HER2 Cell apoptosis & HER2 Cell apoptosis \\
\hline $\operatorname{miR}-519 c$ & $H I F 1 \alpha$ & Angiogenesis \\
\hline $\operatorname{miR}-16$ & Cyclin $E$ & Tumor growth \\
\hline $\operatorname{miR}-497$ & Cyclin E1 & Cell proliferation and invasion \\
\hline $\operatorname{miR}-133 a$ & EGFR Cell cycle and proliferation & EGFR Cell cycle and proliferation \\
\hline $\operatorname{miR}-26 a$ & $M C L-1$ & Cell proliferation and apoptosis \\
\hline $\operatorname{miR}-720$ & $\begin{array}{l}\text { TWIST1 Cell invasion and } \\
\text { migration }\end{array}$ & TWIST1 Cell invasion and migration \\
\hline $\operatorname{miR}-7$ & KLF4 Cancer metastasis & KLF4 Cancer metastasis \\
\hline $\operatorname{miR}-98$ & MMP1, ALK4 Angiogenesis & MMP1, ALK4 Angiogenesis \\
\hline $\operatorname{miR}-542-3 p$ & Angiopoietin-2 & Angiogenesis \\
\hline $\operatorname{miR}-148 a / 152$ & IGF- IR, IRS1 & Angiogenesis \\
\hline
\end{tabular}

Klasifikasi miRNA onkogenik terkait dengan kanker payudara seperti dalam tabel 2 di bawah ini. ${ }^{14}$ Sedangkan untuk miRNA yang berkaitan dengan peranannya sebagai 
tumor supresor pada kanker payudara dapat dilihat pada tabel $3 .{ }^{14}$

Peranan miRNA sebagai biomarker kanker payudara

\section{miRNA sebagai diagnostik}

Beberapa penelitian telah menunjukkan bahwa miR-206 secara signifikan menurun pada pasien kanker payudara dengan reseptor estrogen alfa yang positif. Pada penelitian ini juga menunjukkan bahwa onkogen $m R N A$ adalah target dari dua miRNA (miR-125 dan miR-145) yang dimana kedua miRNA akan mendegradasi mRNA onkogen tersebut sehingga proliferasi sel akan terganggu. pada jaringan kanker payudara akan ditemukan penurunan dari kedua miRNA tersebut. Penurunan beberapa miRNA yang berkaitan dengan kejadian kanker payudara juga dapat ditemukan pada penurunan miR-210, miR-27b, Let-2. Beberapa penelitian juga menunjukkan mutasi dari miR-196a2 dan miR-499 juga berhubungan dengan meningkatnya risiko kanker payudara. Berdasarkan hasil dari penelitian juga didapatkan miRNA b27, 31, 125, 141, 145, a2196, dan kelompok miRNA 200, 205, 206, 210, 429, dan 499 beserta let-7 adalah molekul yang mempunyai kemampuan pre-apoptosis dan menurunkan ekspresi protein onkogen. Dapat disimpulkan bahwa pencegahan kanker seperti kanker payudara dapat dilakukan mungkin dengan meningkatkan ekspresi dari microRNA tersebut. ${ }^{15,16}$ miRNA sebagai prognostik biomarker
miRNA dapat digunakan sebagai prognostik karena beberapa molekul miRNA dapat ditemukan meningkat secara tajam pada kanker payudara yang terlibat pada metastasis dan rekurensi dari penyakit. Sebagai contoh miR-21 adalah onkogen yang berperan terhadap tumorgenesis, metastasis, agresivitas, dan berhubungan dengan prognosis yang buruk pada kanker payudara. Yang menarik adalah target molekul dari miR21 adalah semua gen tumor suppressor, tropomyosin1, programmed cell death protein 4 (PDCD4). ${ }^{15}$ Mikro molekul tersebut memiliki target terhadap protein pengaturan siklus sel dan mempunyai peranan penting dalam proliferasi dan metastasis. Meningkatnya ekspresi miR155 dan miR-9-1 mengindikasikan onkogensitas pada kanker payudara. Meningkatnya miR-301, miR-103/107, miR21, miR-9, miR181b-1, miR-17/92, miR-489, miR-495, miR-200c, dan miR-373. miRNA memiliki kecenderungan untuk meningkatkan kemungkinan untuk terjadinya metastasis kanker payudara. Beberapa miRNA juga mempunyai peran dalam perkembangan agresivitas dan progresivitas kanker payudara, seperti $m i R$ 516-3p, miR-128a, miR-210, dan miR-7. miR-373 dan miR-520c menstimulasi sel kanker untuk bermigrasi dan menjadi lebih agresif. ${ }^{16,17}$

\section{miRNA sebagai prediktif biomarker}

Pada beberapa penelitian yang meneliti miRNA (miR-10b, miR-34a, miR-125b, dan miR-155) sebagai prediktif biomarker. Namun demikian banyak miR-125b yang 
memberikan ekspresi yang paling tinggi terhadap hubungan antara respon kemoterapi pada pasien yang diberikan neoadjuvant. Dimana meningkatnya miR$125 \mathrm{~b}$ sangat berkorelasi dengan kemoresisten. Menurunnya miR-375 dan meningkatnya miR-122 dapat dihubungkan dengan residif dan tidak residifnya kanker payudara. Sedangkan peningkatan miR375, miR-184, miR-1299, dan miR-196a dan menurunnya miR-381, miR-410, dan miR1246 berhubungan dengan baiknya respon kemoterapi neoadjuvant. ${ }^{18,19}$

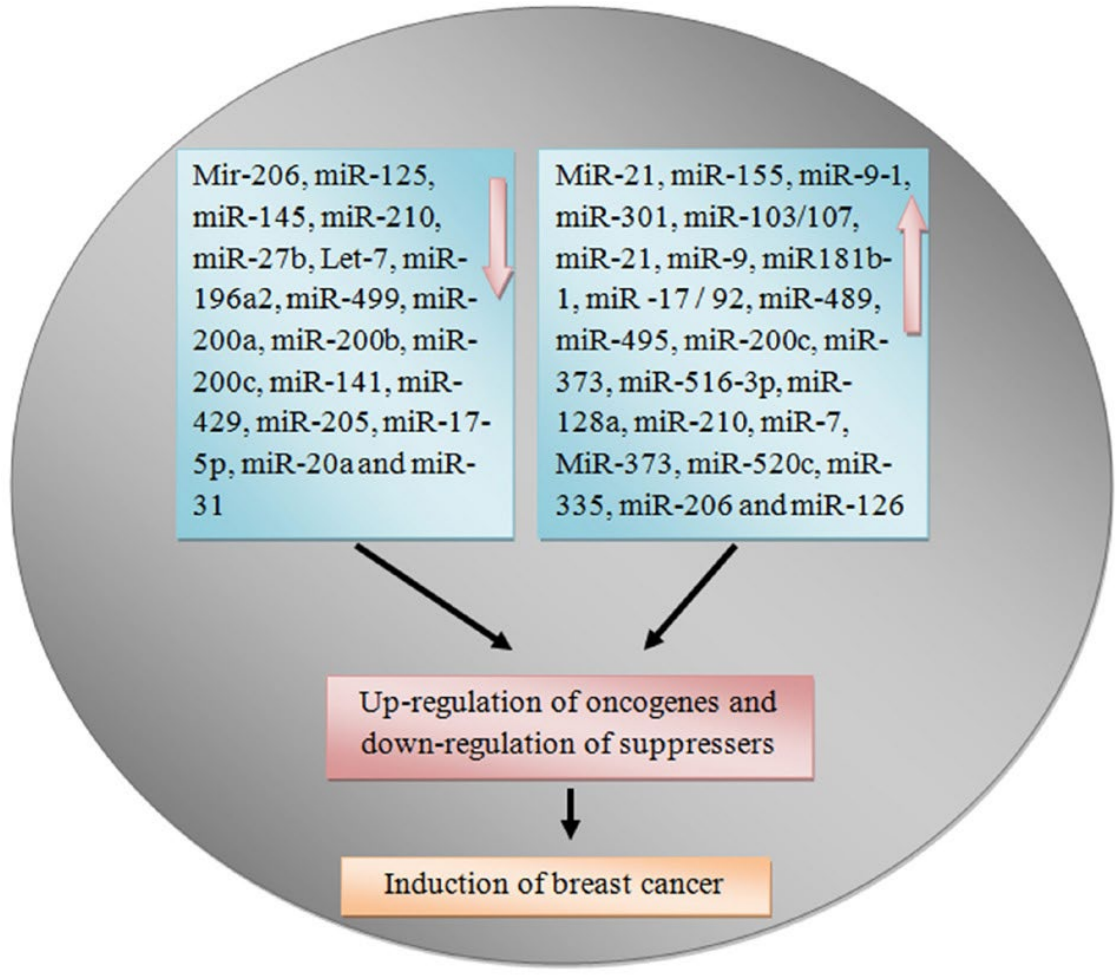

Gambar 3. miRNA sebagai prediktor biomarker kanker payudara. ${ }^{18}$

\section{Peranan miRNA sebagai terapi KPD}

Dari telaah pustaka di atas, telah diketahui bahwa peranan miRNA pada KPD memiliki potensi sebagai biomarker diagnostik, prognostik, prediktor terapi KPD. Mayoritas miRNA dapat digunakan sebagai alat diagnostik dan beberapa sudah diketahui memiliki kemampuan prognosis seperti Let-7, miR-27a, miR-30, miR-155, miR-210, dan miR-335). miRNA juga memiliki potensi untuk memprediksi respon terapi pada kanker payudara hingga saat ini seperti Let-7, miR-7, miR-21, miR-
$26 a / b, \quad \operatorname{miR} 30 b / c, \quad \operatorname{miR}-125 a / b, \quad \operatorname{miR}-182$, miR-204, miR-339-5p, miR-363, miR-365, dan family miR-520. ${ }^{20}$

Ada beberapa miRNA yang saat ini sudah diteliti peranannya dalam pengobatan KPD. Salah satunya adalah miR-145 yang berperan dalam sensitivitas tumor pada terapi radiasi ataupun kemoterapi. Pada penelitian diketahui bahwa dengan mengombinasikan miR-145 dengan kemoterapi atau terapi radiasi akan menghambat proliferasi sel kanker dan meningkatkan sensitivitas terhadap 5- 
Fluoro uracyl (5-FU). ${ }^{21}$ Demikian pula, konstruksi miR-145-adenoviral yang diinjeksikan pada tikus model yang mengalami kanker payudara (in vivo) menurunkan pertumbuhan sel kanker dengan signifikan. Selain itu, pengobatan menggabungkan miR-adenoviral 145-5-FU (5-fluoro uracyl) meningkatkan retardasi pada pertumbuhan tumor payudara dibandingkan pengobatan dengan menggunakan single 5-FU. miR-145 juga diketahui akan meningkatkan sensitivitas molekul target dari obat monoklonal antibodi seperti gefitinib dan vemurafenib. ${ }^{22}$

\section{SIMPULAN}

Mengingat peranan miRNA yang dapat menginduksi dan dapat juga mencegah kanker serta peranannya dalam tingkat agresivitas kanker menjadikan mikro molekul dapat dijadikan biomarker untuk deteksi dini dan penilaian agresivitas kanker payudara. Lepasnya miRNA dari tumor ke dalam sirkulasi darah dapat dijadikan indikator biomarker baik sebagai diagnostik, prognostik, dan prediktif. level ekspresi miRNA juga dapat dijadikan monitor terhadap status tumor, sehingga menjadi catatan penting bahwa pengangkatan primer tumor akan mengurasi jumlah miRNA yang bersirkulasi di dalam darah. Di masa yang akan datang, miRNA dapat digunakan baik sebagai biomarker pada KPD dan juga sebagai bagian dari terapi KPD.

\section{UCAPAN TERIMA KASIH}

Peneliti mengucapkan terima kasih kepada Ricvan Dana Nindrea, M.Kes yang telah membantu dalam proses pengumpulan data dalam penelitian ini.

\section{DAFTAR PUSTAKA}

1. Walsh T, King MC. Ten genes for inherited breast cancer. Cancer Cell. 2007; 11(2):103-5. doi: 10.1016/j.ccr.2007.01.010. [PubMed].

2. Couch FJ, Nathanson KL, Offit K. Two decades after BRCA: setting paradigms in personalized cancer care and prevention. Science. 2014; 343(6178):1466-70. doi: 10.1126/science.1251827. [PubMed].

3. Ginsburg GS, Willard HF. Genomic and personalized medicine: foundations and applications. Transl Res. 2009; 154(6):277-87. doi: 10.1016/j.trsl.2009.09.005. [PubMed].

4. Bird A. Perceptions of epigenetics. Nature. 2007; 447(7143):396-8. doi: 10.1038/nature05913. [PubMed].

5. Lee RC, Feinbaum RL, Ambros V. The C. elegans heterochronic gene lin-4 encodes small RNAs with antisense complementarity to lin-14. Cell. 1993; 75(5):843-54. doi: 10.1016/0092-8674(93)90529y. [PubMed].

6. Sedwick C. Victor Ambros: The broad scope of microRNAs. J Cell Biol. 2013; 201(4):492-3. doi: 10.1083/jcb.2014pi. [PubMed] [PMC free article]. 
7. Walker LO, Avant KC. Strategies for Theory Construction in Nursing (4 ${ }^{\text {th }}$ Edition). New Jersey: Pearson Education, Inc; 2005.

8. Melo CA, Melo SA. Biogenesis and physiology of microRNAs. In: Fabbri M, eds. Non-coding RNAs and Cancer. New York City: Springer; 2013. p5-24. doi: 10.1007/978-1-4614-8444-8 2.

9. Baskerville S, Bartel DP. Microarray profiling of microRNAs reveals frequent coexpression with neighboring miRNAs and host genes. RNA. 2005; 11(3):241-7. doi: 10.1261/rna.7240905. [PubMed] [PMC free article].

10. Kresno SB. Micro-RNA dan implikasinya pada kanker. Indonesian Journal of Cancer. 2011; 5(3):110. [Abstract/FREE full-text].

11. Fu SW, Chen L, Man YG. miRNA biomarkers in breast cancer detection and management. J Cancer 2011; 2:116-22. doi: 10.7150/jca.2.116. [PMC free article].

12. Gustafson D, Tyryshkin K, Renwick N. microRNA-guided diagnostics in clinical samples. Best Pract Res Clin Endrocrinol Metab. 2016; 30(5):563-75. doi: 10.1016/j.beem.2016.07.002. [PubMed].

13. Iorio MV, Croce CM. MicroRNA dysregulation in cancer: Diagnostics, monitoring and therapeutics. EMBO Mol Med. 2012; 4(3):143-59. doi: 10.1002/emmm.201100209. [PubMed] [PMC free article].

14. Wang W, Luo YP. MicroRNAs in breast cancer: oncogene and tumor suppressors with clinical potential. J Zhejiang Univ Sci B. 2015; 16(1):18-31. doi: 10.1631/jzus.B1400184. [PMC free article].

15. Adhami M, Haghdoost AA, Sadeghi B, Malekpour Afshar R. Candidate miRNAs in human breast cancer biomarkers: a systematic review. Breast Cancer. 2018; 25(2):198-205. doi: 10.1007/s12282-017-0814-8. [PubMed].

16. Griffiths-Jones S, Saini HK, van Dongen S, Enright AJ. miRBase: tools for microRNA genomics. Nucleic Acids Res. 2008; 36:D154-8. doi: 10.1093/nar/gkm952. [PubMed] [PMC free article].

17. Bartel DP. MicroRNAs: target recognition and regulatory functions. Cell. 2009; 136(2):215-33. doi: 10.1016/i.cell.2009.01.002. [PubMed] [PMC free article].

18. Calin GA, Croce CM. MicroRNA-cancer connection: the beginning of a new tale. Cancer Res. 2006; 66:7390-7394. doi: 10.1158/0008-5472.CAN-06-0800. [PubMed].

19. Christodoulatos GS, Dalamaga M. Micro-RNAs as clinical biomarkers and therapeutic targets in breast cancer: Quo vadis?. World J Clin Oncol. 2014; 5(2):71-81. doi: 10.5306/wico.v5.i2.71. [PubMed] [PMC free article].

20. Bertoli G, Cava C, Castiglioni I. MicroRNAs: new biomarkers for diagnosis, prognosis, therapy prediction and therapeutic tools for breast cancer. Theranostics. 2015; 5(10):1122-43. doi: 10.7150/thno.11543. [PubMed] [PMC free article].

21. Macfarlane LA, Murphy PR. MicroRNA: biogenesis, function and role in cancer. Curr Genomics. 2010; 11(7):537-561. doi: 10.2174/138920210793175895. [PubMed] [PMC free article].

22. Ikemura K, Yamamoto $M$, Miyazaki S, Mizutani H, Iwamoto $T$, Okuda M. MicroRNA-145 posttranscriptionally regulates the expression and function of P-glycoprotein in intestinal epithelial cells. Mol Pharmacol. 2013; 83(2):399-405. doi: 10.1124/mol.112.081844. [PubMed]. 